\title{
Kepribadian (Five Factor Model) dan Psychological Distress pada Mahasiswa Penerima dan Bukan Penerima Beasiswa
}

\author{
Natasya Julietta Rizky1, Christiana Hari Soetjiningsih ${ }^{2}$ \\ 1,2Fakultas Psikologi, Universitas Kristen Satya Wacana Salatiga \\ 1natasyajulietta.nj@gmail.com, ${ }^{2}$ soetji25@yahoo.co.id
}

Article History:

Received

2021-11-09

Review

2021-12-11

Revised

2021-12-14

Accepted

2021-12-15

Published

2021-12-28
Abstract. Scholarship recipient students have various offers and a greater burden than scholarship recipient students. The demands of lectures can provide pressure that can trigger psychological pressure on students. Each individual is different in assessing the stress experienced depending on the personality. The purpose of the study was to examine the differences and the relationship between personality (five factor model) and psychological difficulties in recipients and non-scholarship recipients. Participants consisted of 40 recipient students and 40 non-scholar recipients. The research instrument used the NEO Five-Factor Inventory-3 scale and the Hopkins Symptom Checklist-25 (HSCL-25) scale. The results of the comparison test show that there is no difference between recipients and non-scholarship recipients. The results of the correlation test show that there is a significant positive relationship between neuroticism and psychological distress, while extraversion and conscientiousness have a significant negative relationship with psychological distress. However, there is no significant relationship between openness to experience and agreeableness to psychological distress.

Keywords: Psychological distress; Five-factor models; Scholarship recipient; Not a scholarship recipient

Abstrak. Mahasiswa penerima beasiswa memiliki berbagai tuntutan dan tanggungjawab lebih besar daripada mahasiswa bukan penerima beasiswa. Tuntutan perkuliahan bisa memberikan tekanan yang dapat memicu distress psikologis pada mahasiswa. Setiap individu berbeda dalam menilai stress yang dialami tergantung pada kepribadian. Tujuan penelitian menguji perbedaan dan hubungan kepribadian (five factor model) dengan distres psikologis pada mahasiswa penerima dan bukan penerima beasiswa. Partisipan terdiri dari 40 mahasiswa penerima dan 40 bukan penerima beasiswa. Instrumen penelitian menggunakan skala NEO Five-Factor Inventory-3 dan skala Hopkins Symptom Checklist-25 (HSCL-25). Hasil uji komparasi menunjukkan tidak ada perbedaan pada penerima dan bukan penerima beasiswa. Hasil uji korelasi menunjukkan terdapat hubungan positif signifikan neurotisme dengan distres psikologis, sedangkan ekstraversi dan kehati-hatian memiliki hubungan negatif signifikan dengan distres psikologis. Namun tidak ada hubungan signifikan antara keterbukaan dan keramah-patutan dengan distress psikologis.

Kata kunci: Psychological distress; Five factor model; Penerima beasiswa; Bukan penerima beasiswa 


\section{Pendahuluan}

Pendidikan merupakan investasi dalam upaya membentuk sumber daya manusia berkualitas yang diharapkan mampu mengambil peran untuk pembangunan berbagai aspek kehidupan di suatu negara (Hapsari dkk., 2018). Sayangnya tidak semua masyarakat Indonesia dapat melanjutkan pendidikan hingga perguruan tinggi. Hal ini terjadi karena tingginya biaya pendidikan yang sulit dijangkau, khususnya bagi masyarakat dengan kondisi ekonomi rendah (Pasaribu, dalam Musabiq dkk., 2018). Oleh karena itu Pemerintah melalui Direktorat Jenderal Pendidikan Tinggi Kementerian Pendidikan dan Kebudayaan berupaya mengalokasikan dana untuk memberikan bantuan biaya pendidikan kepada mahasiswa yang orang tuanya tidak mampu untuk membiayai pendidikannya, dan beasiswa kepada mahasiswa yang mempunyai prestasi tinggi, baik kurikuler maupun ekstrakurikuler (Ramadhon, dkk. 2017). Beasiswa dapat diberikan oleh lembaga pemerintah, perusahaan, yayasan atau instansi lain contohnya Peningkatan Prestasi Akademik (PPA), Bantuan Belajar Mahasiswa (BBM), beasiswa Bank Indonesia, beasiswa Yayasan Supersemar, beasiswa Sampoerna Foundation, dan masih banyak lagi (Wea \& Adiwidjaja, 2018).

Mahasiswa yang menerima beasiswa dihadapkan dengan berbagai tuntutan dan tanggung jawab baik dari kampus maupun pihak yang memberikan beasiswa daripada mahasiswa biasa. Meskipun banyak keuntungan yang didapatkan dari beasiswa namun mahasiswa harus memenuhi persyaratan yang diberikan baik secara akademis dan non akademis. Apabila mahasiswa penerima beasiswa tidak memenuhi persyaratan tersebut maka mahasiswa yang bersangkutan akan mendapatkan surat peringatan dan pemberian bantuan beasiswa terancam tidak dilanjutkan (Musabiq dkk., 2018). Tuntutan dan tanggung jawab di setiap mahasiswa tidak selalu sama dan setiap mahasiswa juga berbeda dalam menghadapi dan menyikapi setiap tuntutan. Tuntutan tersebut, terkadang bisa membuat mahasiswa mengalami tekanan atau membuat mahasiswa merasa tertekan (Tarwiyah dkk., 2019). Tekanan tersebut dapat memicu stress pada mahasiswa.

Menurut Lazarus dan Folkman (1984) stres adalah keadaan dinamis pada hubungan antara individu dengan lingkungannya yang dievaluasi oleh seseorang sebagai tuntutan atau ketidakmampuan dalam menghadapi situasi yang membahayakan atau mengancam kesehatan. Stress dibagi menjadi dua eustress dan distres psikologis, dalam penelitian ini lebih berfokus pada distres psikologis. Menurut Horwitz dan Ridner (dalam Lábate, 2011) distres psikologis adalah paparan peristiwa stress yang mengancam kesehatan fisik atau mental, ketidakmampuan dalam mengatasi stress secara efektif dan perubahan emosi 
yang dihasilkan dari coping yang tidak efektif. Sependapat dengan itu Mirowsky dan Ross (2003) menjelaskan distres psikologis adalah kondisi subjektif yang tidak menyenangkan dalam dua bentuk symptom utama dari depresi (depression) dan kecemasan (anxiety). Depresi cenderung perasaan sedih, kehilangan semangat, kesepian, putus asa atau tidak berharga, sulit tidur, menangis. Kecemasan cenderung gelisah, khawatir, mudah tersinggung dan takut. Mahasiswa juga berisiko mengalami distres psikologis akibat semakin mahalnya biaya kuliah, meningkatnya tuntutan untuk dapat sukses secara akademik, serta tingginya persaingan untuk mendapatkan pekerjaan yang memadai setelah lulus kuliah (Geshica \& Musabiq, 2017).

Setiap individu berbeda dalam menilai stres (stress appraisal) yang dialaminya. Misalnya dalam kondisi sebanding, satu orang merespons dengan amarah, yang lain dengan depresi, yang lain cemas dan yang lain lagi merasa tertantang (Lazarus \& Folkman, 1984). Trait kepribadian adalah salah satu faktor yang mempengaruhi distres dikarenakan trait kepribadian berhubungan dengan kecenderungan emosi individu (Matthews, dalam Azzahra, 2017). Menurut Nasyroh dan Wikansari (2017) five factor model atau model lima factor merupakan pendekatan konsisten untuk melihat dan menilai kepribadian dalam diri seseorang melalui analisis faktor kata sifat, dimana kelima faktor tersebut diantaranya adalah extraversion, agreeableness, openness to experience, neuroticism, dan conscientiousness.

Teori kepribadian Five factor model atau model lima faktor memiliki beberapa keunggulan yaitu dapat digunakan secara universal, sehingga relatif dapat diaplikasikan pada individu dengan budaya yang berbeda (McCrae \& Costa. 2003) serta dapat digunakan dari usia anak-anak hingga dewasa (Thompson, dalam Utami dkk., 2018). Penjelasan lebih detail mengenai Five Factor Model dikemukakan oleh Costa dan McCrae, (1995) yaitu kumpulan domain dari beragam kecenderungan kognitif, afektif, dan perilaku spesifik yang dikelompokkan dalam lima domain neurotisme (neuroticism), ekstraversi (extraversion), keterbukaan (openness to experience), keramah-patutan (agreeableness), kehati-hatian (conscientiousness).

Menurut Costa dan McCrae (dalam Widiger \& Costa, 2013), Neurotisme (neuroticism) mengacu pada tingkat penyesuaian emosional dan ketidakstabilan kronis. Neurotisme mengacu pada individu yang memiliki ide yang tidak realistis, keinginan berlebihan atau kesulitan untuk menoleransi rasa frustasi dan respons koping yang maladaptif. Ekstraversi (extraversion) mengacu pada kuantitas dan intensitas interaksi antar pribadi, tingkat aktivitas, kebutuhan untuk stimulasi dan kapasitas untuk 
kegembiraan. Individu yang ekstraversi cenderung mudah bergaul, aktif, banyak bicara, berorientasi pada orang, optimis, menyenangkan dan penyayang. Keterbukaan (openness to experience) individu yang terbuka penuh dengan rasa ingin tahu, imajinatif, estetik, ingin menghibur dengan nilai-nilai yang tidak biasa. Keramah-patutan (agreeableness) individu dengan keramah-patutan yang tinggi cenderung lembut, baik hati, percaya, pemaaf, membantu orang lain, kerendahan hati dalam menilai kepentingan diri, responsif dan empati. Sedangkan individu yang memiliki keramah-patutan rendah (disebut antagonis) cenderung sinis, kasar, curiga, tidak kooperatif dan mudah tersinggung serta dapat manipulatif, pendendam dan kejam. Terakhir kehati-hatian (conscientiousness) cenderung terorganisir, dapat diandalkan, pekerja keras, mengarahkan diri sendiri, tepat waktu, ambisius, disiplin diri, dan gigih, sedangkan individu yang conscientiousness rendah cenderung tidak memiliki tujuan, tidak dapat diandalkan, malas, ceroboh, lalai, lalai dan hedonistik.

Penelitian yang dilakukan Geshica dan Musabiq (2017) menunjukkan perbedaan signifikan hanya terdapat pada trait kepribadian neuroticism dan openness ditinjau dari jenis kelamin. Selain itu terdapat hanya perbedaan signifikan pada trait kepribadian ekstraversion dan openness ditinjau dari responden yang mengisi kuesioner secara offline dan online. Dilanjutkan oleh penelitian yang sama tidak terdapat perbedaan skor distres psikologis ditinjau dari jenis kelamin, tetapi ada perbedaan skor distres psikologis ditinjau dari responden yang mengerjakan kuesioner secara offline dan online. Disisi lain peneliti belum menemukan penelitian yang membahas mengenai perbedaan five factor model dan psychological distress ditinjau dari penerima beasiswa dan bukan penerima beasisswa.

Dalam penelitian yang dilakukan oleh Nikčević dkk., (2021) menunjukkan extraversion, agreeableness, conscientiousness, dan openness berkorelasi negatif dengan distres psikologis serta neuroticism berkorelasi positif dengan distres psikologis. Berkorelasi positif artinya jika nilai extraversion, agreeableness, conscientiousness, dan openness tinggi maka nilai distres psikologis akan rendah, begitupun sebaliknya. Berkorelasi negatif artinya jika nilai neuroticism tinggi maka nilai distres psikologis juga tinggi, begitupun sebaliknya. Sedikit perbedaan dengan penelitian yang dilakukan oleh Geshica dan Musabiq (2017) didapatkan bahwa adanya hubungan negatif signifikan antara trait kepribadian extraversion, conscientiousness, dan hubungan positif signifikan antara neuroticism terhadap distres psikologis, serta tidak terdapat hubungan signifikan antara trait kepribadian openness dan agreeableness terhadap distres psikologis. Hal tersebut juga didukung oleh penelitian Nouri dkk. (2019), dimana neuroticism yang lebih 
tinggi meningkatkan risiko psychological distress dan skor depresi. partisipan dengan skor extraversion yang lebih tinggi mengalami tingkat depresi yang lebih rendah dan risiko psychological distress yang lebih rendah. Selain itu, skor conscientiousness yang lebih tinggi meningkat secara signifikan, sementara agreeableness menurun skor psychological distress.

Berdasarkan hasil wawacara dengan sebagian mahasiswa penerima dan bukan penerima beasiswa di Fakultas Psikologi Universitas Kristen Satya Wacana (UKSW) didapatkan bahwa sebagian besar mahasiswa penerima beasiswa merasa terbantu dengan bantuan dana dari pemberi beasiswa. Namun ada tanggungjawab lain yang harus diikuti misalkan aktif di kampus dengan mengikuti kepanitiaan atau organisasi, mengikuti kegiatan yang diadakan pemberi beasiswa, nilai IPK tinggi. Hal tersebut cukup memberikan tekanan pada penerima beasiswa. Berbeda dengan mahasiswa bukan penerima beasiswa beban itu lebih banyak di tugas kuliah dan kepanitiaan atau organisasi. Berdasarkan fenomena tersebut, walaupun mahasiswa dihadapkan pada berbagai stressor, nyatanya tidak semua mahasiswa mengalami distres psikologis yang tinggi. Hal tersebut disebabkan karena tiap individu berbeda dalam menilai distres yang dialami tergantung pada trait kepribadian. Disisi lain peneliti belum menemukan penelitian tentang perbedaan five factor model dan psychological distress pada penerima beasiswa dan bukan penerima beasiswa. Oleh karena itu, peneliti tertarik dan bertujuan untuk meneliti perbedaan dan hubungan antara five factor model dan psychological distress pada mahasiswa penerima dan bukan penerima beasiswa sekaligus meneliti hubungan antara five factor model dengan psychological distress

\section{Metode}

\section{Jenis Penelitian}

Jenis penelitian ini adalah penelitian kuantitatif dengan desain penelitian komparasi dan korelasional, yang mana penelitian ini akan membandingkan dua varian kelompok untuk melihat ada tidaknya perbedaan dari tiap kelompok tersebut dan mengetahui hubungan kedua variabel.

\section{Identitas Variabel Penelitian}

Variabel-variabel dalam penelitian ini yaitu:

1. Variabel bebas $(\mathrm{X})$ : Five factor model

2. Variabel terikat $(\mathrm{Y})$ : Psychological distress 
Philanthropy Journal of Psychology

Vol 5 Nomor 2 (2021), 276-294

ISSN 2580-6076 (Print), ISSN 2580-8532 (Online)

\section{Partisipan}

Partisipan berjumlah 80 orang yang terdiri dari 40 mahasiswa penerima beasiswa dan 40 mahasiswa bukan penerima beasiswa. Karakteristik partisipan adalah masih menerima beasiswa dalam bentuk apapun dan mahasiswa aktif Fakultas Psikologi UKSW Salatiga, sedangkan untuk yang bukan penerima beasiswa mempunyai karakteristik mahasiswa aktif dan berasal dari angkatan 2020-2017 Fakultas Psikologi UKSW.

\section{Prosedur penelitian}

Proses pengambilan data dilakukan dari tanggal 15 Juli 2021 sampai 24 Agustus 2021. Penelitian dilakukan dengan membagikan kuesioner dalam bentuk link gforms melalui email student dan whatsapp. Setelah data terkumpul dilanjutkan dengan analisis data menggunakan alat bantu IBM SPSS Statistic 23.

\section{Instrumen Pengumpulan Data}

Instrumen penelitian terdiri dari dua skala psikologis. Untuk psychological distress menggunakan skala Hopkins Symptom Checklist-25 (HSCL-25) yang dikembangkan di Universitas Johns Hopkins, skala ini berjumlah 25 item yang terdiri dari 10 item untuk anxiety dan 25 item untuk depression. Skala dibuat dalam skala Likert untuk alternatif jawaban yang dari 4 alternatif jawaban dari "sangat tidak sesuai" hingga "sangat sesuai". Skala kedua untuk Five factor model menggunakan NEO Five-Factor Inventory- 3 yang merupakan versi pendek dari NEO-PI-R dibuat oleh Costa, P. T \& McCrae, R.R. Jr yang berjumlah 60 item, dimana 12 item untuk neuroticism, 12 item untuk extraversion, 12 item untuk openness, 12 item untuk agreeableness dan 12 item untuk conscientiousness. Skala ini menggunakan skala Likert dan alternatif jawaban dari "sangat tidak setuju" hingga "sangat setuju".

Validitas kedua skala menggunakan validitas isi dan dilakukan reviu oleh dosen pembimbing sebagai expert judgement. Analisis aitem dengan uji daya diskriminasi aitem menggunakan corrected item-total correlation dengan patokan $r$ it $\geq 0,25$ dan uji reliabilitas dengan Alpha Cronbach ( Azwar, 2028). Hasilnya dapat dilihat pada tabel berikut:

Tabel1.

Hasil Uji Daya Diskriminasi dan Reliabilitas

\begin{tabular}{cccc}
\hline Dimensi & r it & Juml.aitem baik & Realiabilitas \\
\hline Neurotisme & $0,259-0,731$ & 12 & 0,840 \\
\hline Ekstraversi & $0,371-0,742$ & 11 & 0,864 \\
\hline Keterbukaan & $0,259-0,441$ & 6 & 0,643 \\
\hline Keramah-patutan & $0,356-0,503$ & 3 & 0,616 \\
\hline Kehati-hatian & $0,282-0,623$ & 11 & 0,798 \\
\hline Distres psi & $0,380-0,734$ & 24 & 0,932 \\
\hline
\end{tabular}




\section{Teknik Analisis Data}

\section{Uji Komparasi}

Analisis statistik untuk uji beda menggunakan independent sample t-test, dengan bantuan aplikasi SPSS ver. 23. Dapat dikatakan ada perbedaan bila memiliki nilai signifikansi $(p<0,05)$, dan tidak ada perbedaan bila memiliki nilai signifikansi $(p>0,05)$. Sebelumnya dilakukan uji asumsi terlebih dahulu yaitu uji normalitas dan uji homogenitas

\section{Uji Korelasi}

Uji korelasi menggunakan pearson correlation dengan alat bantu IBM SPSS Statistic 23. Dapat dikatakan ada hubungan bila memiliki nilai signifikansi $(\mathrm{p}<0,05)$, sedangkan kedua variabel dapat dikatakan tidak ada hubungan bila memiliki nilai signifikansi $(p>0,05)$. Sebelum uji korelasi terlebih dahulu dilakukan uji asumsi yaitu normalitas dan linieritas.

\section{Hasil}

\section{Gambaran Partisipan}

Partisipan dalam penelitian ini dikelompokkan menjadi 2 (dua) yaitu kelompok penerima beasiswa dan kelompok bukan penerima beasiswa. Kedua kelompok ini memiliki karakteristik yang sama yaitu mahasiswa aktif Fakultas Psikologi UKSW Salatiga. Pembedanya adalah kelompok A menerima beasiswa dan kelompok B tidak menerima beasiswa. Rata-rata partisipan menerima beasiswa dari luar kampus, misalnya dari Bidikmisi, perusahaan/instansi atau gereja. Untuk lebih detailnya dapat dilihat pada tabel berikut:

Tabel 2.

Gambaran Partisipan

\begin{tabular}{cccccccccc}
\hline & \multicolumn{3}{c}{ Angkatan } & \multicolumn{2}{c}{ Jenis Kelamin } & \multicolumn{2}{c}{ Jenis Beasiswa } \\
\hline & 2017 & 2018 & 2019 & 2020 & Laki-laki & Perempuan & Prestasi & Rutin & Luar \\
\hline A & 4 & 18 & 14 & 4 & 5 & 35 & 6 & 14 & 20 \\
\hline B & 9 & 13 & 9 & 9 & 5 & 35 & - & - & - \\
\hline A & Penerima Beasiswa & \multicolumn{2}{c}{ B= Bukan penerima beasiswa } & & &
\end{tabular}

\section{Analisis Deskriptif}

Analisa deskriptif dilakukan untuk melihat hasil penelitian berdasarkan rata-rata (mean), standart deviasi, nilai maksimal dan minimal.

\section{Neurotisme (neuroticism)}

Hasil kategorisasi meunjukkan sebagian besar neurotisme pada penerima berada dikategori sedang (35\%), sedangkan neurotisme pada bukan penerima beasiswa berada 
Philanthropy Journal of Psychology

Vol 5 Nomor 2 (2021), 276-294

ISSN 2580-6076 (Print), ISSN 2580-8532 (Online)

dikategori tinggi (37,5\%). Hasil tersebut menunjukkan bahwa ada perbedaan pada mahasiswa penerima dan bukan penerima beasiswa. Untuk lebih jelasnya lihat tabel berikut ini:

Tabel 3.

Kategorisasi Neurotisme (neuroticism)

\begin{tabular}{|c|c|c|c|c|}
\hline Jenis & Kategori & Interval & Jumlah & Presentase \\
\hline \multirow{5}{*}{$\begin{array}{l}\text { Penerima } \\
\text { Beasiswa }\end{array}$} & Sangat tinggi & $x>51,67$ & 2 & $5 \%$ \\
\hline & Tinggi & $43,09<x \leq 51,67$ & 9 & $22,5 \%$ \\
\hline & Sedang & $34,5<x \leq 43,09$ & 14 & $35 \%$ \\
\hline & Rendah & $25,92<x \leq 34,5$ & 13 & $32,5 \%$ \\
\hline & Sangat rendah & $x<25,92$ & 2 & $5 \%$ \\
\hline \multicolumn{5}{|c|}{$S D=8,59 ; M=38,8$} \\
\hline \multirow{5}{*}{$\begin{array}{c}\text { Bukan } \\
\text { Penerima } \\
\text { Beasiswa }\end{array}$} & Sangat tinggi & $x>55,02$ & 2 & $5 \%$ \\
\hline & Tinggi & $46,64<x \leq 55,02$ & 15 & $37,5 \%$ \\
\hline & Sedang & $38,25<x \leq 46,64$ & 10 & $25 \%$ \\
\hline & Rendah & $29,87<x \leq 38,25$ & 10 & $25 \%$ \\
\hline & Sangat rendah & $x<29,87$ & 3 & $7,5 \%$ \\
\hline \multicolumn{5}{|c|}{$S D=8,38 ; M=42,45$} \\
\hline & Jumlah & & 80 & \\
\hline
\end{tabular}

\section{Ekstraversi (extraversion)}

Hasil kategorisasi menunjukkan sebagian besar ekstraversi pada penerima berada dikategori sedang $(47,5 \%)$, begitupun ekstraversi pada bukan penerima beasiswa berada dikategori sedang (45\%). Hasil tersebut menunjukkan bahwa untuk dimensi ekstraversi baik penerima maupun bukan penerima berada di kategori sedang. Untuk lebih jelas lihat tabel berikut ini:

Tabel 4.

Kategorisasi Ekstraversi (extraversion)

\begin{tabular}{|c|c|c|c|c|}
\hline Jenis & Kategori & Interval & Jumlah & Presentase \\
\hline \multirow{5}{*}{$\begin{array}{l}\text { Penerima } \\
\text { Beasiswa }\end{array}$} & Sangat tinggi & $x>50,4$ & 4 & $10 \%$ \\
\hline & Tinggi & $41,98<x \leq 50,4$ & 6 & $15 \%$ \\
\hline & Sedang & $33,56<x \leq 41,98$ & 19 & $47,5 \%$ \\
\hline & Rendah & $25,14<x \leq 33,56$ & 8 & $20 \%$ \\
\hline & Sangat rendah & $x<25,14$ & 3 & $7,5 \%$ \\
\hline \multicolumn{5}{|c|}{$S D=8,42 ; M=37,775$} \\
\hline Bukan & Sangat tinggi & $x>48,72$ & 2 & $5 \%$ \\
\hline Penerima & Tinggi & $41,05<x \leq 48,72$ & 11 & $27,5 \%$ \\
\hline \multirow[t]{2}{*}{ Beasiswa } & Sedang & $33,39<x \leq 41,05$ & 18 & $45 \%$ \\
\hline & Rendah & $25,72<x \leq 33,39$ & 5 & $12,5 \%$ \\
\hline
\end{tabular}


Philanthropy Journal of Psychology

Vol 5 Nomor 2 (2021), 276-294

ISSN 2580-6076 (Print), ISSN 2580-8532 (Online)

Sangat rendah $\mathrm{x}<25,72$

4

$10 \%$

$S D=7,67 ; M=37,225$

Jumlah

80

\section{Keterbukaan (openness to experience)}

Hasil kategorisasi menunjukkan sebagian besar keterbukaan pada penerima berada dikategori sedang sebesar 45\%, sedangkan keterbukaan pada bukan penerima beasiswa mayoritas berada dikategori rendah sebesar 5,5\%. Hasil tersebut menunjukkan bahwa untuk dimensi keterbukaan (openness to experience) baik penerima maupun bukan penerima berada di kategori sedang. Untuk lebih jelasnya lihat tabel berikut ini:

Tabel 5.

Kategorisasi Keterbukaan (openness to experience)

\begin{tabular}{|c|c|c|c|c|}
\hline Jenis & Kategori & Interval & Jumlah & Presentase \\
\hline \multirow{5}{*}{$\begin{array}{l}\text { Penerima } \\
\text { Beasiswa }\end{array}$} & Sangat tinggi & $x>27,7$ & 3 & $7,5 \%$ \\
\hline & Tinggi & $23,16<x \leq 27,7$ & 9 & $22,5 \%$ \\
\hline & Sedang & $18,63<x \leq 23,16$ & 18 & $45 \%$ \\
\hline & Rendah & $14,09<x \leq 18,63$ & 7 & $17,5 \%$ \\
\hline & Sangat rendah & $\mathrm{x}<14,09$ & 3 & $7,5 \%$ \\
\hline \multicolumn{5}{|c|}{$\mathrm{SD}=4,53 ; \mathrm{M}=20,9$} \\
\hline \multirow{5}{*}{$\begin{array}{c}\text { Bukan } \\
\text { Penerima } \\
\text { Beasiswa }\end{array}$} & Sangat tinggi & $x>24,89$ & 2 & $5 \%$ \\
\hline & Tinggi & $21,38<x \leq 24,89$ & 6 & $15 \%$ \\
\hline & Sedang & $17,8<x \leq 21,38$ & 22 & $55 \%$ \\
\hline & Rendah & $14,35<x \leq 17,86$ & 8 & $20 \%$ \\
\hline & Sangat rendah & $x<14,35$ & 2 & $5 \%$ \\
\hline \multicolumn{5}{|c|}{$S D=3,51 ; M=19,62$} \\
\hline & & Jumlah & 80 & \\
\hline
\end{tabular}

\section{Keramah-patutan (agreeableness)}

Hasil ketegorisasi menunjukkan dimensi keramah-patutan (agreeableness) sebagian besar pada penerima berada dikategori sedang sebesar 47,5\%, sedangkan keramahpatutan pada bukan penerima beasiswa berada dikategori sedang sebesar 42,5\%. Hasil tersebut menunjukkan bahwa untuk keramah-patutan baik penerima maupun bukan penerima sama berada pada kategori sedang. Untuk lebih jelasnya lihat tabel berikut ini:

Tabel 6.

Kategorisasi Keramah-patutan (agreeableness)

\begin{tabular}{ccccc}
\hline Jenis & Kategori & Interval & Jumlah & Presentase \\
\hline Penerima & Sangat tinggi & $\mathrm{x}>12,54$ & 2 & $5 \%$ \\
\cline { 2 - 5 } Beasiswa & Tinggi & $10,16<\mathrm{x} \leq 12,54$ & 9 & $22,5 \%$ \\
\cline { 2 - 5 } & Sedang & $7,78<\mathrm{x} \leq 10,16$ & 19 & $47,5 \%$ \\
\cline { 2 - 5 } & Rendah & $5,4<\mathrm{x} \leq 7,78$ & 6 & $15 \%$ \\
\cline { 2 - 5 } & Sangat rendah & $\mathrm{x}<5,4$ & 4 & $10 \%$ \\
\hline
\end{tabular}

$\mathrm{SD}=2,38 ; \mathrm{M}=8,97$ 
Philanthropy Journal of Psychology

Vol 5 Nomor 2 (2021), 276-294

ISSN 2580-6076 (Print), ISSN 2580-8532 (Online)

Bukan

Penerima

Beasiswa

\begin{tabular}{cccc} 
Sangat tinggi & $\mathrm{x}>13,41$ & 3 & $7,5 \%$ \\
\hline Tinggi & $10,3<\mathrm{x} \leq 13,41$ & 7 & $17,5 \%$ \\
\hline Sedang & $7,19<\mathrm{x} \leq 10,3$ & 17 & $42,5 \%$ \\
\hline Rendah & $4,08<\mathrm{x} \leq 7,19$ & 10 & $25 \%$ \\
\hline Sangat rendah & $\mathrm{x}<4,08$ & 3 & $7,5 \%$ \\
\hline
\end{tabular}

$\mathrm{SD}=3,11 ; \mathrm{M}=8,75$

Jumlah

80

\section{Kehati-hatian (conscientiousness)}

Hasil kategorisasi menunjukkan sebagian besar kehati-hatian (conscientiousness) pada penerima berada dikategori sedang sebesar 40\%, sedangkan kehati-hatian pada bukan penerima beasiswa berada dikategori sedang sebesar 45\%. Hasil tersebut menunjukkan bahwa untuk kehati-hatian baik penerima maupun bukan penerima tidak ada perbedaan sama berada di ketegori sedang. Untuk lebih jelasnya lihat tabel berikut ini:

Tabel 7.

Kategorisasi Kehati-hatian (conscientiousness)

\begin{tabular}{|c|c|c|c|c|}
\hline Jenis & Kategori & Interval & Jumlah & Presentase \\
\hline \multirow{5}{*}{$\begin{array}{c}\text { Penerima } \\
\text { Beasiswa }\end{array}$} & Sangat tinggi & $x>48,6$ & 3 & $7,5 \%$ \\
\hline & Tinggi & $42,23<x \leq 48,6$ & 9 & $22,5 \%$ \\
\hline & Sedang & $35,86<x \leq 42,23$ & 16 & $40 \%$ \\
\hline & Rendah & $29,49<x \leq 35,86$ & 10 & $25 \%$ \\
\hline & Sangat rendah & $x<29,49$ & 2 & $5 \%$ \\
\hline \multicolumn{5}{|c|}{$\mathrm{SD}=6,36 ; \mathrm{M}=39,05$} \\
\hline \multirow{5}{*}{$\begin{array}{c}\text { Bukan } \\
\text { Penerima } \\
\text { Beasiswa }\end{array}$} & Sangat tinggi & $x>46,34$ & 3 & $7,5 \%$ \\
\hline & Tinggi & $40,13<x \leq 46,34$ & 7 & $17,5 \%$ \\
\hline & Sedang & $33,91<x \leq 40,13$ & 18 & $45 \%$ \\
\hline & Rendah & $27,7<x \leq 33,91$ & 9 & $22,5 \%$ \\
\hline & Sangat rendah & $x<27,7$ & 3 & $7,5 \%$ \\
\hline \multicolumn{5}{|c|}{$S D=6,21 ; M=37,02$} \\
\hline & & Jumlah & 80 & \\
\hline
\end{tabular}

\section{Distress psikologi}

Hasil kategorisasi menunjukkan sebagian besar distress psikologi pada penerima berada dikategori rendah sebesar 32,5\%, sedangkan distress pada bukan penerima beasiswa berada dikategori sedang sebesar 35\%. Hasil tersebut menunjukkan bahwa adanya perbedaan kategori pada penerima dan bukan penerima beasiswa. Untuk lebih detailnya lihat tabel berikut ini:

Tabel 8.

Kategorisasi Distress Psikologi

\begin{tabular}{ccccc}
\hline Jenis & Kategori & Interval & Jumlah & Presentase \\
\hline Penerima & Sangat tinggi & $\mathrm{x}>72,26$ & 4 & $10 \%$ \\
\cline { 2 - 5 } Beasiswa & Tinggi & $57,85<\mathrm{x} \leq 71,26$ & 10 & $25 \%$ \\
\cline { 2 - 5 } & Sedang & $43,44<\mathrm{x} \leq 57,85$ & 12 & $30 \%$ \\
\hline
\end{tabular}




\begin{tabular}{|c|c|c|c|c|}
\hline & Rendah & $29,03<x \leq 43,44$ & 13 & $32,5 \%$ \\
\hline & Sangat rendah & $x<29,03$ & 1 & $2,5 \%$ \\
\hline \multicolumn{5}{|c|}{$S D=14,4 ; M=50,65$} \\
\hline \multirow{5}{*}{$\begin{array}{c}\text { Bukan } \\
\text { Penerima } \\
\text { Beasiswa }\end{array}$} & Sangat tinggi & $x>81,45$ & 3 & $7,5 \%$ \\
\hline & Tinggi & $65,01<x \leq 81,45$ & 10 & $25 \%$ \\
\hline & Sedang & $48,58<x \leq 65,01$ & 14 & $35 \%$ \\
\hline & Rendah & $32,14<x \leq 48,58$ & 10 & $25 \%$ \\
\hline & Sangat rendah & $x<32,14$ & 3 & $7,5 \%$ \\
\hline \multicolumn{5}{|c|}{$S D=16,43 ; M=56,8$} \\
\hline & & Jumlah & 80 & \\
\hline
\end{tabular}

\section{Analisis Data}

\section{Uji Asumsi}

\section{Uji Normalitas}

Berdasarkan data hasil uji Kolmogorov-Smirnov neurotisme, ekstraversi, keramahpatutan, kehati-hatian dan distress data mendapatkan nilai sig. $p>0,05$, maka neurotisme, ekstraversi, keramah-patutan, kehati-hatian dan distress data berdistribusi normal (simetris). Untuk keterbukaan data tidak berdistribusi normal dikarenakan nilai sig. 0,04 $<0,05$.

\section{Uji linearitas}

Berdasarkan hasil perhitungan uji linearitas didapatkan neurotisme $(0,886)$, ekstraversi $(0,209)$, keterbukaan $(0,765)$, keramah-patutan $(0,064)$, kehati-hatian $(0,236)$ pada distress psikologi, maka ada hubungan yang linear secara signifikan antara Five factor model dan distress psikologi.

\section{Uji Homogenitas}

Uji homogenitas dilakukan dengan menggunakan One-Way ANOVA. Data bersifat homogen apabila nilai signifikansi p $>0.05$. Berdasarkan data hasil uji One-Way ANOVA neurotisme $(0,870)$, ekstraversi $(0,919)$, keterbukaan $(0,066)$, keramah-patutan $(0,141)$, kehati-hatian $(0,571)$ dan distress $(0,664)$ mendapatkan nilai $p>0,05$. Maka dapat disimpulkan bahwa setiap variabel dan dimensi pada penelitian ini data pada penelitian ini bersifat homogen.

\section{Uji Hipotesis}

\section{Uji Komparasi}

Uji komparasi dilakukan untuk melihat ada tidaknya perbedaan antara Five factor model dan distress psikologi pada penerima beasiswa dan bukan penerima beasiswa. Untuk mengetahui hipotesis penelitian ini diterima atau ditolak maka perlu dilakukan uji hipotesis menggunakan $t$-test. Penelitian ini menggunakan uji $t$-test dengan independent 
sampel test untuk data berdistribusi normal (neurotisme, ekstraversi, keramah-patutan, kehati-hatian, distress), sedangkan untuk data tidak berdistribusi normal (keterbukaan) menggunakan uji Mann Whitney $U$ Test, sehingga didapatkan data untuk masing-masing dimensi dan variabel sebagai berikut:

Tabel 9.

Hasil Uji Komparasi

\begin{tabular}{|c|c|c|c|c|}
\hline \multicolumn{5}{|c|}{ Independent Samples Test } \\
\hline & $\mathrm{t}$ & $\mathrm{df}$ & Sig (2-tailed) & $\begin{array}{l}\text { Mean } \\
\text { Difference }\end{array}$ \\
\hline Neurotisme & 1.924 & 78 & .058 & 3.650 \\
\hline Ekstraversi & -.305 & 78 & .761 & .550 \\
\hline Keramah-patutan & .215 & 78 & .831 & .100 \\
\hline Kehati-hatian & -1.440 & 78 & .154 & 2.025 \\
\hline Distress psikologi & 1.743 & 78 & .085 & 6.150 \\
\hline \multicolumn{5}{|c|}{ Uji Mann Whitney U Test } \\
\hline & \multicolumn{2}{|c|}{ Mann-Whitney U } & \multicolumn{2}{|c|}{ Asymp. Sig. (2-tailed) } \\
\hline Keterbukaan & \multicolumn{2}{|c|}{667.000} & \multicolumn{2}{|l|}{.197} \\
\hline
\end{tabular}

1. Neurotisme (neuroticism)

Dapat dilihat pada tabel 9 hasil uji beda t-test menggunakan Uji Independent Sampel T-test, diketahui bahwa ada perbedaan rata-rata antara penerima dan bukan penerima beasiswa sebesar 3,650. Disisi lain juga memaparkan nilai t (t hitung) sebesar 1,924 dengan nilai df (degree of freedom) adalah 78. Sedangkan nilai signifikansi yaitu 0,058 > 0,05 , maka tidak ada perbedaan yang signifikan antara penerima dan bukan penerima beasiswa untuk dimensi neurotisme.

\section{Ekstraversi (extraversion)}

Dapat dilihat pada tabel 9 hasil uji beda T-test menggunakan Uji Independent Sampel T-test, diketahui bahwa ada perbedaan rata-rata antara penerima dan bukan penerima beasiswa sebesar 0,550. Disisi lain juga memaparkan nilai t (t hitung) sebesar -0,305 dengan nilai df (degree of freedom) adalah 78. Sedangkan nilai signifikansi yaitu 0,761 > 0,05, maka tidak ada perbedaan yang signifikan antara penerima dan bukan penerima beasiswa untuk dimensi ekstraversi.

\section{Keterbukaan (openness to experience)}

Dapat dilihat pada tabel 9 hasil uji beda T-test menggunakan Uji Mann Whitney $U$ Test, diketahui bahwa nilai signifikansi yaitu 0,197 >0,05, maka tidak ada perbedaan yang signifikan antara penerima dan bukan penerima beasiswa untuk dimensi ketebukaan.

4. Keramah-patutan (agreeableness) 
Dapat dilihat pada tabel 9 hasil uji beda t-test menggunakan Uji Independent Sampel T-test, diketahui bahwa ada perbedaan rata-rata antara penerima dan bukan penerima beasiswa sebesar 0,100. Disisi lain juga memaparkan nilai t ( $t$ hitung) sebesar 0,215 dengan nilai df (degree of freedom) adalah 78. Sedangkan nilai signifikansi yaitu 0,831 > 0,05 , maka tidak ada perbedaan yang signifikan antara penerima dan bukan penerima beasiswa untuk dimensi keramah-patutan.

5. Kehati-hatian (conscientiosness)

Dapat dilihat pada tabel 9 hasil uji beda T-test menggunakan Uji Independent Sampel T-test, diketahui bahwa ada perbedaan rata-rata antara penerima dan bukan penerima beasiswa sebesar 2,025. Disisi lain juga memaparkan nilai $t$ ( $t$ hitung) sebesar $-1,440$ dengan nilai df (degree of freedom) adalah 78. Sedangkan nilai signifikansi yaitu 0,154 > 0,05, maka tidak ada perbedaan yang signifikan antara penerima dan bukan penerima beasiswa untuk dimensi kehati-hatian.

6. Psychological distress

Dapat dilihat pada tabel 9 hasil uji beda T-test menggunakan Uji Independent Sampel $T$-test, diketahui bahwa ada perbedaan rata-rata antara penerima dan bukan penerima beasiswa sebesar 6,150. Disisi lain juga memaparkan nilai t (t hitung) sebesar 1,743 dengan nilai df (degree of freedom) adalah 78. Sedangkan nilai signifikansi yaitu 0,085 > 0,05 , maka tidak ada perbedaan yang signifikan antara penerima dan bukan penerima beasiswa untuk variabel distress.

\section{Uji Korelasi}

Untuk hubungan antara tiap dimensi yang ada di five factor model dan psychological distress menggunakan pearson correlation. Hasil perhitungan korelasi menunjukkan terdapat hubungan positif signifikan antara neurotisme (neurotism) dan psychological distress $(\mathrm{r}=0,633, \mathrm{n}=80, \mathrm{p}<0,05)$, serta terdapat hubungan negatif signifikan antara ekstraversi (ekstraversion) dan psychological distress $(\mathrm{r}=-0,316, \mathrm{n}=80, \mathrm{p}<0,05)$, terdapat hubungan negatif signifikan antara kehati-hatian (consientiosness) dan psychological distress $(\mathrm{r}=-0,384, \mathrm{n}=80, \mathrm{p}<0,05)$. Sementara itu tidak terdapat hubungan negatif signifikan antara keterbukaan (openness to experience) dan psychological distress ( $\mathrm{r}=-$ $0,143, \mathrm{n}=80, \mathrm{p}>0,05)$, dan tidak terdapat hubungan negatif signifikan antara keramahpatutan (agreeableness) dan psychological distress $(\mathrm{r}=-0,200, \mathrm{n}=80, \mathrm{p}>0,05)$.

Tabel 10.

Hasil Uji Korelasi

$\begin{array}{llll}\text { Five Factor Model } & \text { Psychological Distress } & \text { Sig. } & \text { N }\end{array}$

(r) 


\begin{tabular}{lccc}
\hline Neurotisme & 0.633 & 0,000 & 80 \\
Ekstraversi & $-0,316$ & 0,004 & 80 \\
Keterbukaan & $-0,143$ & 0,206 & 80 \\
Keramah-patutan & $-0,200$ & 0,075 & 80 \\
Kehati-hatian & $-0,384$ & 0,000 & 80 \\
\hline
\end{tabular}

\section{Diskusi}

\section{Perbedaan five factor model dan psychological distress pada penerima dan bukan penerima beasiswa}

Berdasarkan hasil uji beda dimana dimensi neuroticism nilai sig. 0,058 ( $\mathrm{p}>0,05)$; extraversion nilai sig. 0,761 ( $\mathrm{p}>0,05)$; openness to experience nilai sig. 0,197 ( $\mathrm{p}>0,05)$; agreeableness nilai sig. 0,831 ( $p>0,05)$; conscientiousness nilai sig. 0,154 ( $p>0,05)$, artinya tidak adanya perbedaan antara dimensi kepribadian neurotisme (neuroticism), ekstraversi (extraversion), keterbukaan (opennes to experience), keramah-patutan (agreeableness), kehati-hatian (conscientiousness) pada penerima dan bukan penerima beasiswa.

Hal tersebut didukung oleh penelitian yang dilakukan Ningsah dan Kuncoro (2017) bahwa tidak ada perbedaan Five factor model (neuroticism, extraversion, opennes to experience, agreeableness, conscientiousness) pada wanita narapidana dan wanita non narapidana. Walau berbeda dalam setting partisipan tetapi masih menunjukkan hal yang sama, artinya tipe kepribadian Five factor model pada penerima dan bukan penerima beasiswa maupun wanita narapidana dan non narapidana sama. Hal tersebut didukung penelitian Steca dkk., (2018) yang dilakukan di Italia menunjukkan atlet yang paling sukses dalam olahraganya mendapat skor lebih tinggi daripada non-atlet di setiap dimensi Five factor model, kecuali keterbukaan (openness to experience), sementara atlet yang kurang sukses mendapat skor lebih tinggi daripada non-atlet hanya dalam ekstraversi (extraversion) dan keramah-patutan (agreeableness). Atlet yang lebih sukses menunjukkan keramah-patutan (agreeableness), kehati-hatian (consientiosness), dan neurotisme (neuroticism) yang lebih tinggi daripada atlet yang kurang sukses.

Hal tersebut juga berlaku untuk distress psikologis, dengan nilai sig. 0,085 ( $p>0,05)$, yang artinya tidak menunjukkan adanya perbedaan antara penerima dan bukan penerima beasiswa. Hal tersebut berbeda dengan tingkat distress yang dialami antara perempuan dan laki-laki. Mirowsky dan Ross (2003) menyatakan bahwa perempuan lebih rentan mengalami distress psikologis dibandingkan dengan laki-laki. Hasil penelitian Agustine dan Borualogo (2021) menunjukkan distress psikologis anak dan remaja perempuan lebih tinggi dibandingkan anak dan remaja laki-laki. Hal tersebut disebabkan oleh anak dan remaja perempuan dan laki-laki berbeda dalam cara menghayati dan mengekspresikan 
gangguan psikologis. Hal ini di dukung oleh penelitian Jatmika (2020) terdapat perbedaan psychological distress pada mahasiswa laki-laki dan perempuan, dikarenakan perempuan lebih mengandalkan social support daripada laki-laki yang menggunakan resiliensi dalam menghadapi stressor. Prevalensi psychological distress pada mahasiswi lebih tinggi (94,07\%) dibandingkan mahasiswa (89,11\%) (Zhang, 2018).

Hasil kategorisasi menunjukan adanya perbedaan neurotisme (neuroticism) dan distress pada penerima dan bukan penerima beasiswa. Neuroticism penerima beasiswa berada di kategori sedang, sedangkan bukan penerima beasiswa berada di kategori tinggi. Individu yang tinggi pada dimensi neurotisme cenderung gugup, sensitif, tegang dan mudah cemas, sedangkan orang rendah dalam dimensi ini cenderung tenang dan santai (Friedman \& Schustack, 2008). Untuk distress psikologis penerima beasiswa berada di kategori rendah sedangkan bukan penerima berada di kategori sedang. Penelitian yang didapatkan Geshica dan Musabiq (2017) dimana ketika nilai neurotisme tinggi maka nilai distress juga tinggi. Individu dengan neuroticism tinggi cenderung gugup, sensitif, tegang dan mudah cemas (Friedman \& Schustack, 2008). Menurut McCrae dan Costa (dalam Feist et al., 2017) Neuroticism menggambarkan kerentanan terhadap emosi yang tidak menyenangkan seperti kemarahan, kecemasan, depresi, atau kerentanan. Kondisi saat ini di mana proses pembelajaran jarak jauh yang merupakan pengalaman baru bagi mahasiswa menyebabkan mahasiswa mengalami culture shock. Selain culture shock, beban belajar baik berupa beban tugas maupun beban jadwal perkuliahan yang padat juga menjadi faktor yang menyebabkan mahasiswa mengalami kecemasan (NurCita \& Susantiningsih, 2020). Dalam perkuliahan banyak stressor yang muncul dan jenis stressor yang dimiliki mahasiswa berasal dari intrapersonal yaitu kondisi keuangan dan tanggung jawab di organisasi kampus (Musabiq \& Karimah, 2018).

\section{Hubungan five factor model dan psychological distress pada penerima dan bukan penerima beasiswa}

Hasil uji korelasi menunjukkan bahwa terdapat hubungan positif signifikan pada trait kepribadian neurotisme (neuroticism) terhadap psychological distress, sedangkan ekstraversi (extraversion) dan kehati-hatian (conscientiousness) memiliki hubungan negatif signifikan dengan psychological distress. Namun tidak ada hubungan signifikan antara keterbukaan (opennes to experience) dan keramah-patutan (agreeableness) terhadap distress psikologis. Hal ini sejalan dengan penelitian yang dilakukan oleh Geshica dan Musabiq (2017) dimana extraversion dan conscientiousness berhubungan negatif signifikan terhadap psychological distress. Sementara itu, neuroticism berhubungan positif 
dan signifikan terhadap distres psikologis. Tidak ditemukan hubungan signifikan pada agreeableness dan openness terhadap psychological distress.

Individu dengan neurotisme cenderung menilai masalah secara negatif dengan emosi yang tidak menyenangkan seperti kemarahan, kecemasan, depresi, atau kerentanan (McCrae \& Costa, dalam Feist dkk., 2017). Hal tersebut membuat individu dengan neurotisme tinggi rentan mengalami distress psikologis. Neurotisme menjadi faktor kerentanan untuk kecemasan kesehatan dan kecemasan umum dan gejala depresi (Nikčević dkk., 2021).

Individu dengan ekstraversi cenderung mudah bergaul, aktif, banyak bicara, berorientasi pada orang, optimis, menyenangkan dan penyayang (Costa \& McCrae, dalam Widiger \& Costa, 2013). Selain itu individu extraversion tinggi memiliki dukungan sosial yang memadai karena senang menjalin interaksi dengan individu lain dan penuh kasih sayang (Costa \& McCrae, 1994). Hal ini membuat individu extraversion tinggi maka tingkat distres psikologis rendah, begitupun sebaliknya.

Individu dengan kehati-hatian (conscientiousness) cenderung terorganisir, dapat diandalkan, pekerja keras, mengarahkan diri sendiri, tepat waktu, ambisius, disiplin diri, dan gigih (Costa \& McCrae, dalam Widiger \& Costa, 2013). Oleh karena itu individu dengan conscientiousness akan mengorganisir masalah atau tekanan yang ia hadapi, misalnya tugas kuliah, organisasi, dll. Hal itu yang menyebabkan jika individu dengan conscientiousness tinggi cenderung memiliki tingkat psychological distress rendah. Namun hal ini berbeda dengan penelitian Musabiq dkk., (2021) dimana tidak ada hubungan antara conscientiousness dan distress psikologis pada dewasa muda suku Jawa.

Individu dengan keterbukaan (openness to experience) cenderung memiliki rasa ingin tahu, imajinatif, estetik, ingin menghibur dengan nilai-nilai yang tidak biasa. Individu dengan openness tinggi lebih menyadari pemikiran, impuls, serta emosinya, sehingga mengalami emosi positif dan negatif sama intensnya, sehingga membuat arah hubungan openness dan distress psikologis berbeda-beda antar studi (Geshica \& Musabiq, 2017). Dalam penelitian ini openness tidak memiliki hubungan signifikan dengan psychological distress, namun berbeda dengan penelitian Musabiq dkk., (2021) dimana terdapat hubungan positif signifikan antara openness dan distres psikologis.

Individu dengan keramah-patutan (agreeableness) cenderung ramah, penolong, penurut, dan pemaaf (Costa \& McCrae, 1994). Agreeableness secara negatif dan langsung berhubungan dengan kecemasan dan gejala depresi (Nikčević dkk., 2021). Individu dengan agreeableness tinggi maka tingkat distres psikologis akan rendah. 


\section{Simpulan}

Simpulan penelitian yaitu tidak adanya perbedaan five factor model dan distress pada penerima dan bukan penerima beasiswa Fakultas Psikologi Universitas Kristen Satya Wacana. Tidak ada perbedaan dimensi neurotisme (neuroticism) antara penerima dan bukan penerima beasiswa. Hal tersebut juga diikuti oleh dimensi ekstraversi (extraversion), keterbukaan (openness to experience), keramah-patutan (agreeableness), kehati-hatian (conscientiousness) dan variabel distress yang menunjukkan tidak adanya perbedaan antara penerima dan bukan perima beasiswa. Selain itu, ditemukan hubungan positif signifikan pada neurotisme (neuroticism) terhadap psychological distress, sedangkan ekstraversi (extraversion) dan kehati-hatian (conscientiousness) memiliki hubungan negatif signifikan dengan distres psikologis. Namun tidak ada hubungan signifikan antara keterbukaan (opennes to experience) dan keramah-patutan (agreeableness) terhadap distress psikologis.

\section{Saran}

Penelitian ini masih berfokus pada penerima beasiswa di lingkup Fakultas Psikologi, alangkah lebih baik jika penelitian yang sama atau serupa dilakukan pada lingkup yang lebih luas. Selain itu untuk penelitian selanjutnya dapat menambah data kualitatif agar data yang didapatkan semakin dalam dan kaya. Penelitian selanjutnya juga diharapkan menambah variabel yang bisa dibahas selain Five factor model dan distress dalam ranah penerima beasiswa.

\section{Kepustakaan}

Agustine, T. C., \& Borualogo, I. (2021), Pengaruh distress psikologis terhadap resiliensi pada anak dan remaja saat pandemic Covid-19. Prosiding Psikologi, 7(2), 257-262.

Azzahra, F. (2017). Pengaruh resiliensi terhadap distress psikologis pada mahasiswa. Jurnal Ilmiah Psikologi Terapan, 5(1), 80-96.

Baird, M. B., LeMaster, J. W., \& Harding, A. (2016). Translation and cultural adaptation of the Hopkins Symptom Checklist-25 (HSCL-25) into Nepalese for use with bhutanese refugees. Online Journal of Cultural Competence in Nursing and Healthcare, 6 (1), 1430.

Baird, B. M., \& Skariah, E. (2016). Translating the Hopkins Symptom Checklist-25 (HSCL25) into Dinka, a South Sudanese tribal language. The International Journal for Translation \& Interpreting Research, 8(2), 96-109.

Costa, P. T., Jr., \& McCrae, R. R. (1995). Domains and facets: hierarchical personality assessment using the revised NEO Personality Inventory. Journal of personality assessment, 64(1), 21-50. 
Gaol, N. T. L. (2016). Teori stres: stimulus, respons, dan transaksional. Buletin Psikologi, 24(1), 1-11.

Feist, J., Feist, G. J., \& Roberts, T. (2017). Teori kepribadian (edisi 8). Jakarta Selatan: Salemba Humanika.

Friedman, H. S \& Schustack, M. W., (2008). Kepribadian teori klasik dan riset modern (edisi ketiga). Jakarta: Penerbit Eerlangga.

Geshica, L., \& Musabiq, S. A. (2017). Hubungan trait kepribadian dan distres psikologis pada mahasiswa: sebuah aplikasi dari Five Factor Model. Jurnal Psikologi Klinis Indonesia, 1(1), 5-17.

Hapsari, D. T., Harini, \& Nugroho, J. A. (2018). Pengaruh beasiswa PPA dan kebiasaan belajar terhadap prestasi belajar mahasiswa FKIP UNS penerima beasiswa PPA Periode Januari - Juni 2017. Jurnal Pendidikan Bisnis dan Ekonomi, 4(1), 1-15.

Hutapea, C. D. A., \& Mashoedi, S. F. (2019). Hubungan antara optimisme dan distres psikologis pada emerging adults miskin di DKI Jakarta. Mindset, 10(2), 87 - 103.

Jatmika, D. (2020). Hubungan antara psychological distress dan problematic internet use pada mahasiswa. Prosiding Seminar Nasional dan Call paper, 268-278.

Lazarus, R. S., \& Folkman, S. (1984). Stress, appraisal, and coping. New York: Springer.

Lábate, L. (2011). Mental illnesses: understanding, prediction and control. Rijeka: InTech.

McCrae, R. R., \& Costa, P. T. (2008). Empirical and theoretical status of the five-factor model of personality traits. In The SAGE Handbook of Personality Theory and Assessment: Volume 1 - Personality Theories and Models (pp. 273-294). SAGE Publications Inc.. https://doi.org/10.4135/9781849200462.n13

McCrae, R. R., \& Costa, P. T. (2003). Personality in adulthood: a five-factor theory perspective (ed. 2). New York: Guilford Press.

Mirowsky, J., \& Ross, C.E. (2003). Social causes of psychological distress. New York, USA: Aldine de Gruyter.

Musabiq, S. A., Assyahidah, L. N., Sari, A., Dewi, H. U. K., \& Erdiaputri, W. A. (2018). Stres, motivasi berprestasi, bersyukur, dan perceived social support: analisis optimisme pada mahasiswa penerima beasiswa Bidikmisi. Mediapsi, 4(1), 22-35.

Musabiq, S. A., \& Karimah, I. (2018). Gambaran stress dan dampaknya pada mahasiswa. Insight, 20 (2), 74-80.

Musabiq, S., Karimah, I., Geshica, L., Poerwandari, E., \& Karimah. (2021). Tribe, personality, and psychological distress: relationship between personality trait and psychological distress in Young Adult Javanese Tribe. College Student Journal (55)2, 219-230.

Nasyroh, M., \& Wikansari, R. (2017). Hubungan antara kepribadian (Five factor model model) dengan kinerja karyawan. Jurnal Ecopsy, 4(1), 10-16.

Nikčević, A. V., Marino, C., Kolubinski, D. C., Leach, D., \& Spada, M. M. (2021). Modelling the contribution of the big five personality traits, health anxiety, and COVID-19 psychological distress to generalised anxiety and depressive symptoms during the COVID-19. Journal of Affective Disorders 279, 578-584. doi: https://doi.org/10.1016/j.jad.2020.10.053

Ningsah, K.R., \& Kuncoro, J. (2017). Persepsi terharap perilaku tindak kiminal ditinjau dari kepribadian the big five \& status hukum wanita narapinada \& wanita non narapidana. Jurnal Psikologi Proyeksi, 12(1), 27-34.

Nouri, F., Feizi, A., Afshar, H., Keshteli, A.vH., \& Adibi, P. (2019). How five-factor personality traits affect psychological distress and depression? results from a large populationbased study. Psychological Studies, 64(1), 59-69.

NurCita, B., \& Susantiningsih, T. (2020). Dampak pembelajaran jarak jauh dan psysical distancing pada tingkat kecemasan mahasiswa Fakultas Kedokteran Universitas Pembangunan Nasional “Veteran” Jakarta. Journal of Borneo Holistic Health, 3(1), 5868. 
Ramadhon, R., Jaenudin, R., \& Fatimah, S. (2017). Pengaruh beasiswa terhadap motivasi belajar mahasiswa pendidikan ekonomi Universitas Sriwijaya. Jurnal Provit, 4(1), 203-213.

Rizal, J. G., \& Wedhaswary, I. D. (2020, Agustus 11). Pandemi Covid-19, apa saja dampak pada sektor ketenagakerjaan Indonesia. Kompas .com. https://www.kompas.com/tren/read/2020/08/11/102500165/pandemi-covid19-apa-saja-dampak-pada-sektor-ketenagakerjaan-indonesia-?page=all.

Steca, P., Baretta, D., Andrea, G., D'Addario., \& Monzani, D. (2018). Associations between personality, sports participation and athletic success. A comparison of Big Five in sporting and non-sporting adults. Personality and Individual Differences, 121(), 176183. doi: $10.1016 /$ j.paid.2017.09.040

Tarwiyah, A., Mayasari, S., \& Pratama, M. J. (2019). Identifikasi stressor akademik pada mahasiswa tahun ketiga. Jurnal Bimbingan Konseling 8(1), 1-15.

Utami, S. A., Grasiaswaty, N., \& Akmal, S. Z. (2018). Hubungan tipe kepribadian berdasarkan big five theory personality dengan kebimbangan karir pada Siswa SMA. Jurnal Psikogenesis, 6(1), 11-18.

Wea, A. G., \& Adiwidjaja, I. (2018). Pengaruh beasiswa terhadap motivasi dan prestasi belajar mahasiswa Universitas Tribhuwana Tunggadewi Malang. JISIP: Jurnal Ilmu Sosial dan Ilmu Politik, 7(1), 21-25.

Widiger, T. A., \& Costa, P. T., Jr. . (2013). Personality disorders and the five factor model of peronality (Ed. 3). Washington, DC: American Psychological Association.

Zhang, M., Zhang, J., Zhang, F., Zhang, L., Feng, D. (2018). Prevalence of psychological distress and the effects of resilience and perceived social support among Chinese college students: Does gender make a difference?. Psychiatry Research, 267, 409413. doi:10.1016/j.psychres.2018.06.038 